\title{
Entamoeba histolytica Trophozoites Induce an Inflammatory Cytokine Response by Cultured Human Cells through the Paracrine Action of Cytolytically Released Interleukin-1a
}

\author{
Lars Eckmann, ${ }^{*}$ Sharon L. Reed, ${ }^{* \neq}$ Jennifer R. Smith, * and Martin F. Kagnoff* \\ Departments of *Medicine and ${ }^{\ddagger}$ Pathology, University of California, San Diego, La Jolla, California 93093
}

\begin{abstract}
Infection with the protozoan parasite Entamoeba histolytica results in a high mortality worldwide. To initiate infection, $E$. histolytica trophozoites in the bowel lumen penetrate the epithelium, and cause extensive lysis of host cells. The acute amebic lesions in animal models are characterized by infiltration with inflammatory cells, particularly neutrophils. The acute host response is likely important for determining whether the infection will spread systemically, but little is known regarding the signals which initiate an acute inflammatory response to $E$. histolytica. In the studies reported herein, we used an in vitro model system to define the proinflammatory signals produced by epithelial and other host cells in response to infection with $E$. histolytica trophozoites. Coculture of human epithelial and stromal cells and cell lines with trophozoites is shown to increase expression and secretion of an array of chemoattractant and proinflammatory cytokines, including IL-8, GRO $\alpha$, GM-CSF, IL-1 $\alpha$, and IL-6. Moreover, high-level secretion of those cytokines is regulated by the paracrine action of cytolytically released IL-1a. A second mechanism for trophozoite-induced IL-8 production involves trophozoite-target cell contact via a galactose-inhibitable amebic adherence protein, and appears to be mediated through increased intracellular calcium levels. These studies define novel mechanisms through which acute inflammation can be initiated in the host in response to a cytolytic pathogen, such as $E$. histolytica. (J. Clin. Invest. 1995. 96:1269-1279.) Key words: amebiasis • neutrophils • interleukin-8 • inflammation • epithelial cells
\end{abstract}

\section{Introduction}

Entamoeba histolytica infects $\sim 500$ million people worldwide and results in a mortality, among parasitic infections, that is exceeded only by malaria and schistosomiasis (1). The majority of individuals remain asymptomatic and spontaneously clear the infection (2). Nonetheless, in $\sim 10 \%$ of individuals, the trophozoites invade the bowel or enter the circulation and cause dysentery or hepatic abscesses. The course and final outcome of infection depends on a number of parasite factors, including

Address correspondence to Lars Eckmann, Department of Medicine, 0623D, University of California, San Diego, 9500 Gilman Drive, La Jolla, CA 92093-0623. Phone: 619-534-4625; FAX:619-534-5691.

Received for publication 18 January 1995 and accepted in revised form 25 May 1995.

J. Clin. Invest.

(C) The American Society for Clinical Investigation, Inc.

0021-9738/95/09/1269/11 \$2.00

Volume 96, September 1995, 1269-1279 the virulence of the infecting strain (3-12), and host factors which can alter the risk and severity of invasive disease (13-18).

To initiate symptomatic infection, $E$. histolytica trophozoites in the bowel lumen penetrate the mucus layer and adhere to the underlying mucosa. Trophozoite attachment to host epithelial and inflammatory cells and to colonic mucins and bacteria is mediated by a lectin specific for galactose $/ N$-acetyl-galactosamine (19-21). In rodents, changes are seen in epithelial cells, including microvillus shortening and damage to the apical portion of cells, before direct trophozoite contact (22). Initial steps in tissue invasion may be aided by the release from trophozoites of neutral cysteine proteases which are capable of degrading components of the extracellular matrix (23). Trophozoites then lyse colonic epithelial cells and penetrate into the underlying mucosa, where they are in close contact with stromal cells such as fibroblasts and smooth muscle cells, and inflammatory cells. Trophozoite penetration into the mucosa is associated with a local infiltration with PMNs in experimental models (22, 24, 25 ), but data on the earliest lesions in humans are limited. Lysis of host cells may be mediated by pore-forming peptides (26), phospholipases (27), or hemolysins (28). Similar events in the liver indicate that the host inflammatory response in that site is initiated also by the interaction between trophozoites and host cells (29-31). In contrast to the acute $E$. histolytica infection, chronic amebic abscesses in the liver contain few acute inflammatory cells (32).

Little is known regarding the host signals that initiate an acute inflammatory response to $E$. histolytica. The studies reported herein have used an in vitro model system to define the proinflammatory signals produced by host cells in response to infection with $E$. histolytica trophozoites. We show that coculture of human epithelial cells with $E$. histolytica trophozoites results in secretion of an array of potent chemoattractant and proinflammatory cytokines, including IL-8, GRO $\alpha$, GM-CSF, IL- $1 \alpha$, and IL-6. Moreover, we demonstrate that increased IL-8 and GM-CSF secretion after $E$. histolytica infection is regulated predominantly by the cytolytic release of preformed IL- $1 \alpha$. A second mechanism for trophozoite induced IL-8 production involves trophozoite-target cell contact via a galactose-inhibitable amebic adherence protein. These studies define novel mechanisms through which acute inflammation can be initiated in the host in response to a cytolytic pathogen such as $E$. histolytica.

\section{Methods}

Reagents. The following cytokines and antibodies were used in these studies: recombinant human (rh) ${ }^{1}$ TNF $\alpha$ (Genentech, Inc., South San Francisco, CA); rh IL- $\alpha$ and IL-1 $\beta$ (Immunex Corp., Seattle, WA);

1. Abbreviation used in this paper: $\mathrm{rh}$, recombinant human; IL-1Ra, IL1 receptor antagonist. 
rh IL-8 (R\&D Systems, Inc., Minneapolis, MN); rh IL-1 receptor antagonist (IL-1Ra) (R\&D Systems, Inc.), polyclonal goat antibodies against human IL- $1 \alpha$, IL-1 $\beta$, and TNF $\alpha$ (R\&D Systems, Inc.); monoclonal mouse antibodies against human IL- $1 \alpha$ (Genzyme Corp., Cambridge, MA) and normal goat IgG (Sigma Chemical Co., St. Louis, MO). Dgalactose and $\beta$-D-fructose were obtained from Calbiochem Corp. (La Jolla, CA). D- $(+)$-glucose and $N$-acetyl-D-galactosamine were purchased from Sigma Chemical Co.

$E$. histolytica trophozoites. The axenic $E$. histolytica strain HM1:IMSS was obtained from the American Type Culture Collection (ATCC, Rockville, MD), and trophozoites were grown in TYI-S-33 medium at $37^{\circ} \mathrm{C}$. Before infection of cell monolayers, trophozoites were washed twice in ice-cold PBS and resuspended in DME with $10 \%$ FCS. Trophozoites were viable under these conditions for at least 6-8 h. Conditioned medium was prepared by incubating trophozoites $\left(10^{7} / \mathrm{ml}\right)$ in PBS for $3 \mathrm{~h}$ and collecting the supernatant after centrifugation at $3000 \mathrm{~g}$ for $5 \mathrm{~min}(23,33)$.

Cells. The following human cell lines were obtained from the ATCC: HT29 colon adenocarcinoma cells (HTB 38), SW620 colon adenocarcinoma cells (CCL 227), I407 embryonic intestinal cells (CCL 6), CCD18Co normal colon fibroblasts (CRL 1459), HISM normal jejunal smooth muscle cells (CRL 1692) (34), HeLa cervix epithelioid carcinoma cells (CCL 2), WI38 normal diploid lung fibroblasts (CCL 75), and HepG2 hepatocellular carcinoma cells (HB 8065). Cells were grown in DME medium supplemented with $10 \%$ FCS, 20 mM Hepes, and $2 \mathrm{mM}$ glutamine in $10 \% \mathrm{CO}_{2}, 90 \%$ air at $37^{\circ} \mathrm{C}$. T84 human colon carcinoma cells were obtained initially from $\mathrm{K}$. Dharmsathaphorn and were grown in 50\% DME, 50\% Ham's F12 medium supplemented with $5 \%$ newborn calf serum and $2 \mathrm{mM}$ glutamine. PMNs were prepared from freshly drawn venous blood as described by others (35).

Infection protocol. Cells were seeded into 6- or 24-well plates and grown to confluency. Monolayers were washed once, and washed trophozoites in growth medium were added. Cultures were incubated for $8 \mathrm{~h}$ and supernatants were removed, filtered through a $0.22-\mu \mathrm{m}$ filter and cytokine concentrations were measured. To determine the number of viable cells in the monolayers, the cultures were washed twice with ice-cold PBS to remove dead and adherent trophozoites, and the remaining cells were removed from the plates using trypsin/EDTA. Cells were centrifuged, resuspended in $0.4 \%$ trypan blue in PBS, and viable cells were counted. Control experiments had shown that the number of viable cells determined by this method correlated closely with the total protein content of the monolayers.

Cytokine assays. Cytokine concentrations were determined by ELISA. IL-8 ELISAs were performed as described previously (36) and were sensitive to $20 \mathrm{pg} / \mathrm{ml}$. Bioactivity of secreted $\Pi \mathrm{L}-8$ was assessed by measuring secretion of myeloperoxidase from purified human PMNs (35). IL-1 $\alpha$ ELISAs used optimal concentrations of monoclonal mouse anti-human IL-1 $\alpha$ antibody (Genzyme Corp.) as capturing antibody, and polyclonal rabbit anti-human IL- $1 \alpha$ antibody (Endogen, Inc., Boston, MA) as detecting antibody. Alkaline phosphatase-labeled monoclonal mouse anti-rabbit IgG (Sigma Chemical Co.) was used as a second-step antibody. Bound alkaline phosphatase was visualized with the substrate $p$-nitrophenylphosphate (Sigma Chemical Co.). The IL$1 \alpha$ ELISA was sensitive to $5 \mathrm{pg} / \mathrm{ml}$ recombinant IL- $1 \alpha$. IL-6 ELISAs used monoclonal mouse anti-human IL-6 (R\&D Systems Inc.) as capturing antibody, polyclonal rabbit anti-human IL-6 (Endogen Inc.,) as detecting antibody and the same second-step reagents as described for IL-1 $\alpha$. The IL-6 ELISA was sensitive to $50 \mathrm{pg} / \mathrm{ml}$. The GM-CSF and GRO $\alpha$ ELISAs (Quantikine; R\&D Systems Inc.,) were sensitive to 5 $\mathrm{pg} / \mathrm{ml}$ and $20 \mathrm{pg} / \mathrm{ml}$, respectively.

$R N A$ extraction and reverse transcription-PCR analysis. Total cellular RNA was extracted from cells using an acid guanidinium thiocyanate-phenol-chloroform method (37). Quantitative reverse transcription-PCR analysis of mRNA levels for IL-8, IL-1 $\alpha$, GM-CSF, IL-6, and $\beta$-actin was performed as described previously using internal RNA standards (38). This method was sensitive to $<10^{3}$ mRNA molecules per microgram total RNA.

Reporter gene constructs and transfection experiments. To construct the IL-8 reporter vector pIL8/luc, we amplified a 1.4-kb fragment of the IL-8 promoter (39) from human DNA by PCR using the oligonucleotides 5'-ATCTGAAGCTTGAGCTCGAATTCAGTAACCCAGGCATTATTTTATC-3' and 5'-TTGTCCTAGAAGCTTGTGTGCTCTGCTGTC-3'. The PCR product was inserted into the unique HindIII site of p19LUC, a plasmid containing the gene for firefly luciferase (40). The identity of the insert was confirmed by dideoxy sequencing using Sequenase (United States Biochemical Corp. Cleveland, $\mathrm{OH}$ ). To construct the $\beta$-actin reporter vector $\mathrm{p} \beta$ act/luc, the luciferase gene from the vector pGL2Basic (Promega Corp., Madison, WI) was amplified using the oligonucleotides 5'-GTCAGTCGACCGGTACTGTTGGTAAAATGG-3' and 5'-CTGCAAGCTTCGCTGAATACAGTTACATTTTAC-3'. The amplified fragment was inserted between the unique SalI and HindIII sites of the plasmid $\mathrm{pH} \beta$ APr-1-neo which contains a 4.3-kb fragment of the human $\beta$-actin promoter (41). To correct for differences in transfection efficiencies and cell numbers, the expression vector $\mathrm{pRSV} / \mathrm{lacZ}$ (Promega Corp.) was used in which the expression of the gene for bacterial $\beta$-galactosidase is controlled by the long terminal repeat of Rous sarcoma virus.

Cells were transfected with reporter gene constructs using a calcium precipitation method as described previously (42). Briefly, subconfluent HeLa cell cultures in $10-\mathrm{cm}$ dishes were transfected with $10 \mu \mathrm{g}$ each of $\mathrm{pIL} 8 / \mathrm{luc}$ and $\mathrm{pRSV} / \mathrm{lacZ}$, or $\mathrm{p} \beta$ act/luc and pRSV/lacZ. After $24 \mathrm{~h}$, cells were seeded into 24-well plates and incubated for an additional $24 \mathrm{~h}$, after which they were used for infections. Cell lysates were prepared using $200 \mu \mathrm{l} /$ well of $0.5 \%$ Triton $\mathrm{X}-100,0.1 \mathrm{M}$ potassium phosphate ( $\mathrm{pH} 7.8$ ), 1 mM DTT. Luciferase activity was assayed by addition of $100 \mu \mathrm{l}$ extract to $100 \mu \mathrm{l}$ of $1 \mathrm{mM}$ D-luciferin and $100 \mu \mathrm{l}$ of $20 \mathrm{mM}$ ATP (pH 7.4) in a buffer of $35 \mathrm{mM}$ glycylglycine ( $\mathrm{pH} \mathrm{7.8),} 20 \mathrm{mM}$ $\mathrm{MgCl}_{2}$, and light release was quantitated for $10 \mathrm{~s}$ using a luminometer (Monolight 2010; Analytical Luminescence Laboratory, San Diego, CA). $\beta$-galactosidase activity was determined using the chemiluminescent substrate AMPGD (3-(4-methoxyspiro[1,2-dioxetane-3,2' tricyclo[3.3.1.1 $\left.1^{3,7}\right]$ decan ]-4-yl) phenyl- $\beta$-D-galactopyranoside; Tropix Inc., Bedford, MA) as described before (43). Briefly, $50 \mu$ l extract was added to $500 \mu \mathrm{l}$ of $16 \mu \mathrm{g} / \mathrm{ml}$ AMPGD, $0.1 \mathrm{M}$ sodium phosphate ( $\mathrm{pH}$ 8.4), $1 \mathrm{mM} \mathrm{MgCl}_{2}$ and incubated for $60 \mathrm{~min}$ at room temperature. Light release was induced by addition of $100 \mu l 0.2 \mathrm{~N} \mathrm{NaOH}$ containing $10 \%$ Emerald enhancer (Tropix Inc.), and quantitated for $10 \mathrm{~s}$ in a luminometer. Increased transcription from the IL- 8 and $\beta$-actin promoters in response to $E$. histolytica infection were calculated by comparing ratios of luciferase to $\beta$-galactosidase activities in cells cotransfected with pIL8/luc and pRSV/LacZ, or $\mathrm{p} \beta$ act/luc and $\mathrm{pRSV} / \mathrm{lacZ}$, respectively, with the ratios in uninfected controls. Nontransfected cells were used as a background control.

Western blot analysis. Cell lysates were prepared by sonication of confluent monolayers in 6-well plates in $2 \mathrm{ml}$ DME supplemented with $10 \%$ FCS. Immunoprecipitations were carried out using optimal concentrations of monoclonal mouse anti-human IL- $\alpha$ (R\&D Systems Inc.,) as primary antibody and affinity-purified anti-mouse IgG agarose (Sigma Chemical Co.) as secondary antibody. Samples were denatured by boiling in $2 \%$ SDS, size-fractionated on a $12.5 \%$ SDS-polyacrylamide gel, and electrophoretically transferred to a nitrocellulose membrane $(0.1-\mu \mathrm{m}$ pore size $)$. Immunodetection was performed using optimal concentrations of polyclonal rabbit anti-human IL- $1 \alpha$ antibody (Endogen Inc., Boston, MA) as primary antibody, and a peroxidaselabeled anti-rabbit IgG antibody (Amersham Corp., Arlington Heights, IL) as secondary antibody. Specifically bound peroxidase was detected by enhanced chemiluminescence (ECL System; Amersham Corp) and exposure to $\mathrm{x}$-ray film for $15-30 \mathrm{~s}$. Band intensities were quantitated with a densitometer.

\section{Results}

Human cell lines cocultured with $E$. histolytica trophozoites secrete an array of chemoattractant and proinflammatory cytokines, including IL-8, GRO $\alpha, G M-C S F$, and IL-6. Neutrophils accumulate rapidly at the site of acute $E$. histolytica infection $(24,25,29-31)$, yet the responsible host signals are not known. 


\begin{tabular}{|c|c|c|c|c|c|}
\hline \multirow[b]{3}{*}{ Cells } & \multicolumn{5}{|c|}{ Addition to culture } \\
\hline & \multirow{2}{*}{$\frac{\text { None }}{\text { IL-8 secreted }}$} & \multicolumn{2}{|c|}{ E. histolytica } & \multicolumn{2}{|c|}{$\mathrm{TNF} \alpha$} \\
\hline & & IL-8 secreted & $\begin{array}{l}\text { Fold increase } \\
\text { over control }\end{array}$ & IL-8 secreted & $\begin{array}{l}\text { Fold increase } \\
\text { over control }\end{array}$ \\
\hline & $p g / m l$ & $p g / m l$ & & $p g / m l$ & \\
\hline T84 colon epithelial cells & $68 \pm 21^{\ddagger}$ & $752 \pm 121^{\ddagger}$ & 11 & $11,251 \pm 4,593^{\ddagger}$ & 165 \\
\hline HT29 colon epithelial cells & $96 \pm 20$ & $740 \pm 108$ & 7.7 & $95,810 \pm 22,264$ & 998 \\
\hline SW620 colon epithelial cells & $92 \pm 37$ & $478 \pm 112$ & 5.2 & $4,334 \pm 780$ & 47 \\
\hline I407 embryonic intestinal cells & $212 \pm 65$ & $18,401 \pm 933$ & 87 & $4,500 \pm 524$ & 21 \\
\hline CCD-18Co colon fibroblasts & $118 \pm 25$ & $1,919 \pm 576$ & 16 & $36,328 \pm 10,891$ & 308 \\
\hline HISM intestinal smooth muscle cells & $416 \pm 26$ & $3,566 \pm 96$ & 8.6 & $38,325 \pm 6,847$ & 92 \\
\hline HeLa cervix epithelial cells & $179 \pm 87$ & $27,969 \pm 4,808$ & 156 & $5,418 \pm 1,517$ & 30 \\
\hline WI38 lung fibroblasts & $1,403 \pm 111$ & $92,088 \pm 7,717$ & 66 & $225,835 \pm 7,151$ & 161 \\
\hline HepG2 liver cells & $54 \pm 9$ & $668 \pm 140$ & 12 & $1,281 \pm 77$ & 24 \\
\hline
\end{tabular}

* Confluent monolayers of human cell lines in 6-well plates were infected with $2-5 \times 10^{5} \mathrm{E}$. histolytica trophozoites/well in a 2 -ml vol and incubated for $8 \mathrm{~h}$. Parallel cultures were incubated for $8 \mathrm{~h}$ in the presence of $200 \mathrm{ng} / \mathrm{ml} \mathrm{TNF} \alpha$ or no added stimuli. After incubation, supernatants were removed and the concentration of IL-8 was determined by ELISA, as described in Methods. ${ }^{\ddagger}$ Numbers represent mean \pm SEM of the results of at least three independent experiments.

Several cytokines are known to be potent chemoattractants and activators of neutrophils, including members of the C-X-C family of chemokines such as IL-8 and GRO $\alpha$, and hemopoietic growth factors such as GM-CSF. Thus, we asked whether human cells cocultured with $E$. histolytica are induced to secrete these cytokines. We first investigated $\mathrm{IL}-8$ as a prototype member of the C-X-C family of chemokines. As shown in Table I, coculture of several human epithelial cell lines, nontransformed human fibroblasts and intestinal smooth muscle cells and human liver cells with $E$. histolytica trophozoites resulted in a 5- to 150 -fold increase in IL-8 secretion. The lower IL-8 response of some cells to $E$. histolytica infection (e.g., T84, HT29) was not related to the inability to secrete high levels of $\mathrm{IL}-8$, since stimulation with TNF $\alpha$ increased IL-8 secretion by those cells to levels comparable to that of the higher responding cells (Table I).

In addition to IL-8, secretion of GRO $\alpha$ and GM-CSF, cytokines that influence the localization, activation, and survival of neutrophils, was increased in response to $E$. histolytica infection, as shown in Table II for HeLa and WI38 cells. We also analyzed secretion of IL-6 since $E$. histolytica infection can induce an acute phase response (44). IL-6 secretion increased after coculture of HeLa and WI38 cells with $E$. histolytica trophozoites (Table II). Taken together, these findings indicate that cells respond to $E$. histolytica infection with increased secretion of an array of cytokines, which includes IL-8, GRO $\alpha$, GM-CSF, and IL-6.

Since secretion of all the proinflammatory cytokines tested increased in response to $E$. histolytica infection, our subsequent studies focused on the mechanisms that underlie increased secretion of the prototypic proinflammatory cytokine IL-8. As shown in Fig. 1, maximal IL-8 secretion was confined to a relatively narrow range of trophozoite inoculum. Little IL-8 secretion was seen below $5 \times 10^{4}$ trophozoites/well using 6well plates ( $9.3 \mathrm{~cm}^{2}$ growth area), and maximal levels of IL-8 secretion were observed at $2.5-5 \times 10^{5}$ trophozoites/well, which equals a cell:trophozoite ratio of $\sim 15: 1$ to $2: 1$ (Fig. 1). However, further increases in the ratio of trophozoites to cells resulted in decreased IL-8 secretion, a finding which likely related to the decreased number of viable cells at the end of the incubation period in monolayers that were infected with these larger trophozoite inocula (Fig. 1). Comparison of the doseresponse curves for IL-8 secretion and cell lysis indicated that maximal IL-8 secretion was obtained when $\sim 50 \%$ of the monolayer was lysed.

Secreted IL-8 was bioactive, as tested in HeLa cells, since supernatants of $E$. histolytica-infected cell cultures stimulated the release of myeloperoxidase by freshly isolated human PMNs (35), and this activity was completely blocked by addition of anti-IL-8 antibodies (data not shown). No IL-8 activity was released by trophozoites cultured alone. Moreover, incubation of rhIL-8 with $E$. histolytica trophozoites in the culture medium used in these studies for $8 \mathrm{~h}$ did not alter IL-8 bioactivity.

Time course of increased IL-8 secretion and IL- 8 mRNA

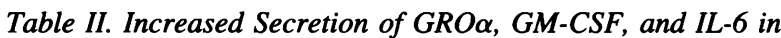
HeLa and WI38 Cells after E. histolytica Infection*

\begin{tabular}{lcccc}
\hline & & \multicolumn{3}{c}{ Cytokine secretion } \\
\cline { 3 - 5 } Cytokine & Cells & $\begin{array}{c}\text { Control } \\
(\mathrm{pg} / \mathrm{ml})\end{array}$ & $\begin{array}{c}+ \text { E. histolytica } \\
(\mathrm{pg} / \mathrm{ml})\end{array}$ & $\begin{array}{c}\text { Ratio infected/ } \\
\text { control }\end{array}$ \\
\hline GRO $\alpha$ & HeLa & $<20$ & $2,967 \pm 1,129^{\ddagger}$ & $>148$ \\
& WI38 & $194 \pm 45$ & $10,689 \pm 635$ & 55 \\
GM-CSF & HeLa & $<5$ & $187 \pm 34$ & $>37$ \\
& WI38 & $14 \pm 3$ & $357 \pm 12$ & 26 \\
IL-6 & HeLa & $54 \pm 24$ & $6,458 \pm 2,182$ & 120 \\
& WI38 & $168 \pm 40$ & $16,184 \pm 6,852$ & 96
\end{tabular}

* Confluent monolayers of HeLa and WI38 cells in 6-well plates were infected with $2-5 \times 10^{5} E$. histolytica trophozoites and incubated for 8-12 h, after which cytokine concentrations in the supernatants were determined by ELISA. In parallel, uninfected cultures were used as controls. ${ }^{\ddagger}$ Data are means \pm SEM of the results from three independent experiments. 


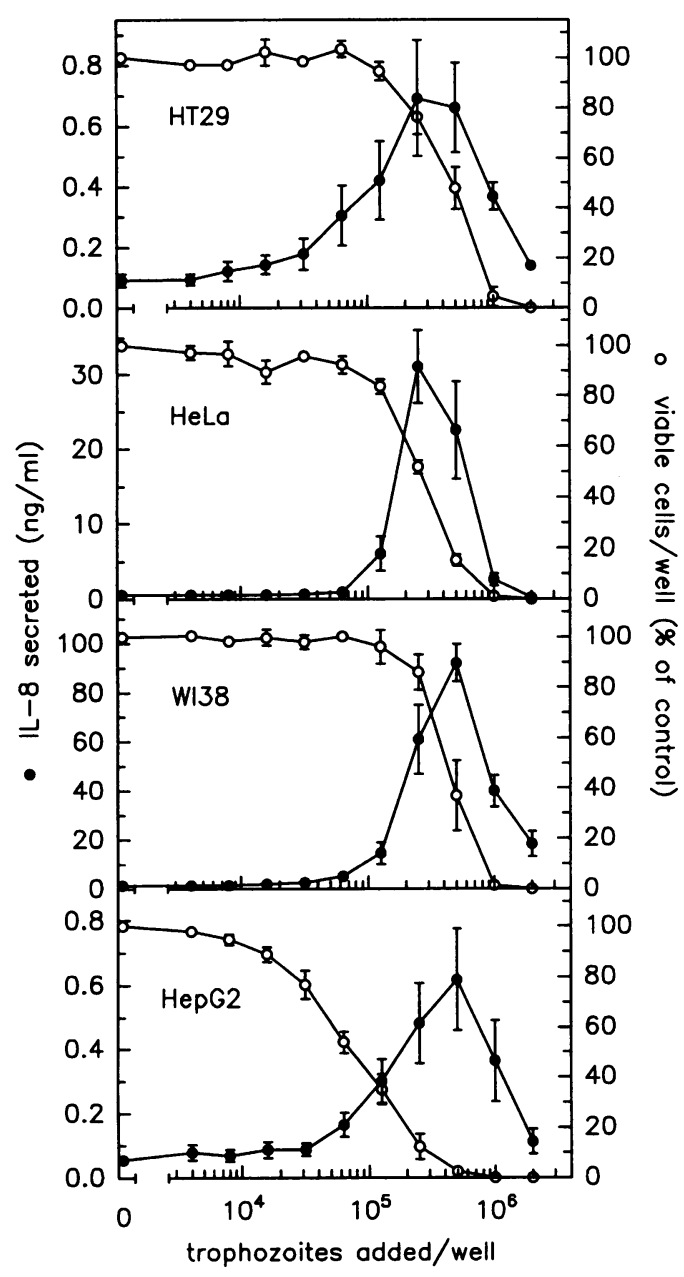

Figure 1. Relationship between $E$. histolytica trophozoite inoculum and IL-8 secretion. Confluent monolayers of HT29, HeLa, WI38, and HepG2 cells in 6-well plates were cocultured for $8 \mathrm{~h}$ with varying numbers of E. histolytica trophozoites in a 2-ml vol, after which IL-8 concentrations in the supernatants were measured by ELISA $(\bullet)$. In parallel, the number of viable cells remaining in the monolayers at the end of the culture period was determined by trypan blue dye exclusion, and is expressed as a percentage of the number of viable cells present in uninfected control cultures $(O)$. Values are mean \pm SEM of the results from at least three independent experiments. Control cultures contained a mean of $3.7 \times 10^{6}\left(\mathrm{HT}_{29}\right), 7.1 \times 10^{5}(\mathrm{HeLa}), 1.7 \times 10^{6}(\mathrm{WI} 38)$, and 3.6 $\times 10^{6}($ HepG2) cells/well.

levels after addition of E. histolytica trophozoites. A time course analysis of the IL- 8 response revealed that IL- 8 secretion by cells was increased within 2 to $4 \mathrm{~h}$ after addition of $E$. histolytica trophozoites, and reached a maximum at $4-6 \mathrm{~h}$ in HT29 cells, and $8 \mathrm{~h}$ in HeLa cells (Fig. $2 \mathrm{~A}$, top). Cell lysis was observed within $2 \mathrm{~h}$ and cell numbers continued to decrease for $6-10 \mathrm{~h}$ after the addition of trophozoites (Fig. 2 A, bottom). After 8-10 $h$ in culture, most trophozoites were dead and, concomitantly, no further reduction in the number of cells in the monolayers was seen beyond this point.

Levels of IL-8 mRNA after infection of HT29 and HeLa monolayers with $E$. histolytica were assayed at different times after infection by quantitative reverse transcription-PCR (38). As shown in Fig. $2 B$, levels of IL-8 mRNA increased within 1 to $2 \mathrm{~h}$ after addition of the trophozoites to the monolayers and reached a maximum between 2 (HT29) and $8 \mathrm{~h}$ (HeLa)
A
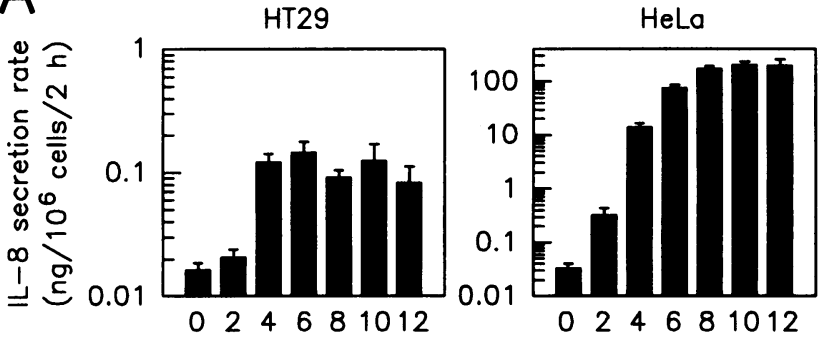

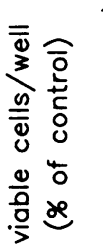
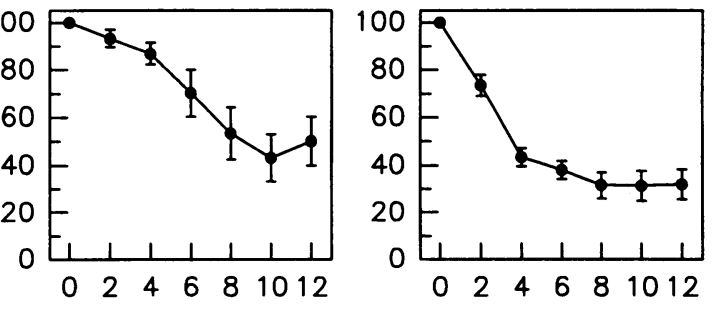

hours after infection

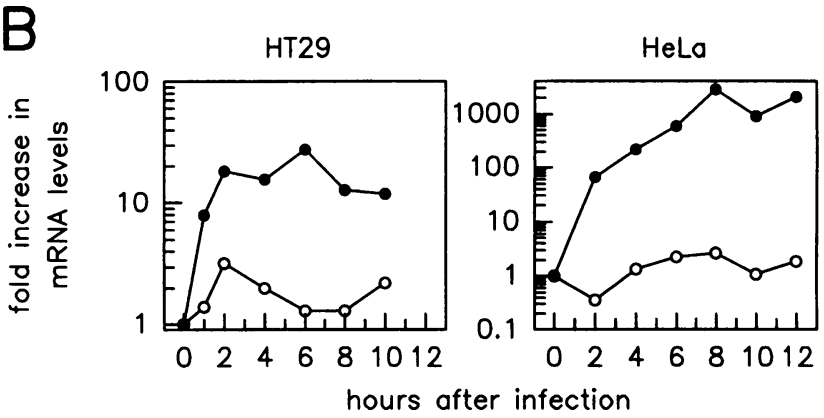

Figure 2. IL-8 secretion rates and IL-8 mRNA levels after addition of E. histolytica trophozoites. Confluent monolayers of HT29 and HeLa epithelial cells in 6-well plates were infected with $2-5 \times 10^{5} \mathrm{E}$. histolytica trophozoites/well in a 2-ml vol. (A) Supernatants were removed at different times after infection, and the IL-8 concentration was assayed by ELISA. In parallel, the number of viable cells in the monolayers was determined by trypan blue exclusion. Values are mean \pm SEM of the results of three independent experiments. $(A, t o p)$ IL-8 secretion rates. IL- 8 secretion for consecutive 2 -h periods was calculated by subtracting the amount of IL-8 in the supernatants at the beginning of each 2-h period from the amount at the end of that period. To obtain the IL8 secretion rate, the amount of IL-8 secreted during each 2-h period was divided by the number of viable cells in the monolayers at the end of the respective 2-h period. Hours after infection refers to the end of each 2-h period after infection. The " $0 \mathrm{~h}$ " value refers to the IL-8 secretion rate in uninfected cultures during a 2-h period. $(A$, bottom $)$ Number of viable cells. The number of viable cells remaining at different times after infection was determined, and is expressed as a percentage of the number of viable cells present in uninfected control cultures. Control cultures contained a mean of $4.3 \times 10^{6}\left(\right.$ HT29) and $1.0 \times 10^{6}$ ( $\mathrm{HeLa}$ ) cells/well. (B) Total cellular RNA was extracted at different times after addition of trophozoites to the monolayers. mRNA levels for IL-8 $(\bullet)$ and $\beta$-actin (O) were determined by quantitative reverse transcription-PCR analysis using internal standard RNAs, as described in Methods, and are expressed as fold increase over the levels in unstimulated control cultures. Control cultures contained $1.1 \times 10^{4}($ HT29) and $1.1 \times 10^{5}(\mathrm{HeLa})$ IL-8 mRNA molecules $\mu \mathrm{g}$ total cellular RNA, and $5.0 \times 10^{6}(H T 29)$ and $1.8 \times 10^{8}(\mathrm{HeLa}) \beta$-actin mRNA molecules/ $\mu \mathrm{g}$ RNA.

after infection. IL- 8 mRNA levels in HT29 cells increased by 10- to 20-fold, while levels in HeLa cells increased $\sim 1,000$ fold. No significant differences in levels of $\beta$-actin mRNA were 


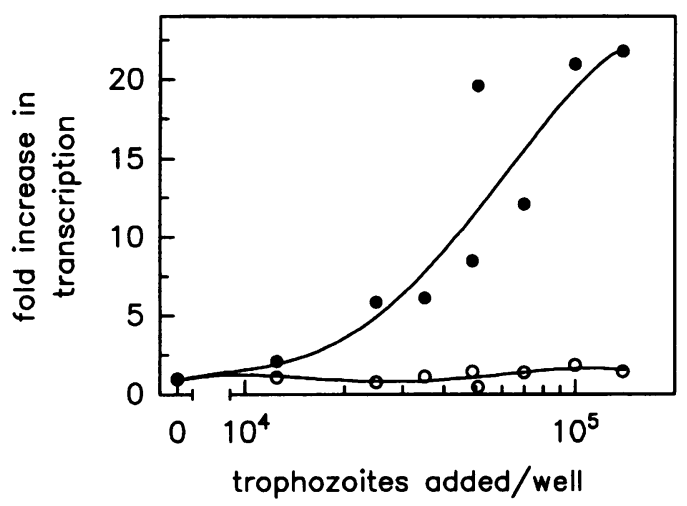

Figure 3. Transcription from the IL-8 promoter is increased in HeLa cells after $E$. histolytica infection. HeLa cells were cotransfected with the reporter constructs pIL8/luc and pRSV/lacZ, or $p \beta a c t / l u c$ and $\mathrm{pRSV} / \mathrm{lacZ}$, as described in Methods. $48 \mathrm{~h}$ after transfection, the monolayers were infected with different numbers of $E$. histolytica trophozoites as indicated and $10 \mathrm{~h}$ after infection, cell extracts were prepared and assayed for luciferase and $\beta$-galactosidase activities. Changes in transcription from the IL-8 $(\bullet)$ and $\beta$-actin (O) promoters in response to $E$. histolytica infection were assessed by comparing the ratios of luciferase to $\beta$-galactosidase activity in cells cotransfected with $\mathrm{pIL}-8 /$ luc and $\mathrm{pRSV} / \mathrm{lacZ}$, or $\mathrm{p} \beta$ act/luc and $\mathrm{pRSV} / \mathrm{lacZ}$. Increased transcription is expressed as the fold increase in transcription in E. histolytica-infected compared to uninfected control cells.

detected in infected and control cultures (Fig. 2 B). mRNA levels for GM-CSF and IL-6 were similarly increased 1,000and 250 -fold, respectively, in HeLa cells after coculture with $E$. histolytica trophozoites. Thus, unstimulated HeLa cells contained $1 \times 10^{3} \mathrm{GM}-\mathrm{CSF}$ and $4 \times 10^{4} \mathrm{IL}-6 \mathrm{mRNA}$ molecules/ $\mu \mathrm{g}$ total cellular RNA, respectively. In contrast, after $8 \mathrm{~h}$ coculture with $E$. histolytica, HeLa cells contained $1 \times 10^{6} \mathrm{GM}$-CSF and $1 \times 10^{7} \mathrm{IL}-6 \mathrm{mRNA}$ molecules $/ \mu \mathrm{g}$ total RNA, respectively.

Increased transcription from the IL-8 promoter in cells cocultured with $E$. histolytica. To assess whether increased $\mathrm{IL}-8$ mRNA levels in response to $E$. histolytica infection were due to increased IL-8 gene transcription, we constructed a vector containing a chimeric reporter gene in which a $1.4-\mathrm{kb}$ fragment of the human IL-8 promoter was placed in front of the gene for firefly luciferase (pIL8/luc). An expression vector containing the bacterial $\beta$-galactosidase gene under the control of the long terminal repeat of Rous Sarcoma Virus (pRSV/lacZ) and a luciferase vector driven by the human $\beta$-actin promoter ( $\mathrm{p} \beta$ act/ luc) were used as controls. pIL8/luc and pRSV/lacZ, or $\mathrm{p} \beta$ act/ luc and pRSV/lacZ were cotransfected into HeLa cells, and $E$. histolytica trophozoites were added to the cultures $48 \mathrm{~h}$ later. At different times after infection, cell extracts were assayed for luciferase and $\beta$-galactosidase activities. Increased transcription from the IL-8 promoter was observed in HeLa cells within $2 \mathrm{~h}$ after infection. By $10 \mathrm{~h}$ after infection, transcription was increased by $>20$-fold, whereas transcription of the $\beta$-actin gene was unchanged (Fig. 3).

$I L-1 \alpha$ in cell lysates activates $I L-8$ secretion. Since maximal IL-8 secretion occurred under conditions which resulted in cell lysis, we reasoned that cell components released during lysis may stimulate the remaining viable cells in the monolayers to secrete IL-8. To test this possibility, cell lysates were prepared from intact monolayers by sonication, and their effect on IL-8 secretion by viable cell monolayers was determined. As shown in Fig. 4 for HeLa and WI38 cells, cell lysates induced IL-8

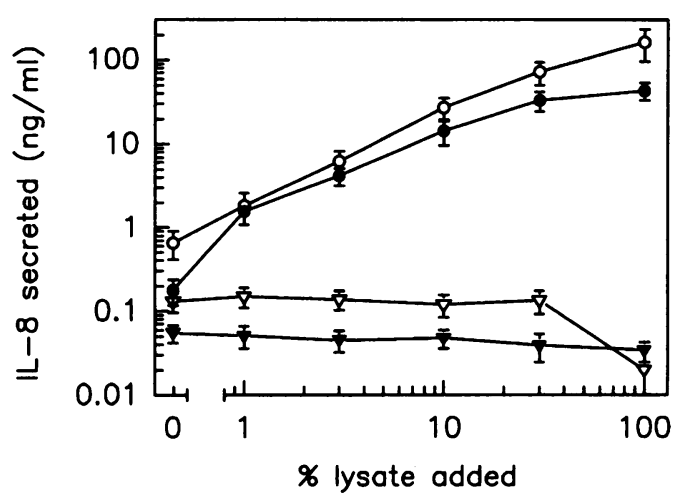

Figure 4. Induction of IL-8 secretion by cell lysates. HeLa (•), WI38 $(0)$, HepG2 ( $\nabla)$ and HT29 $(\nabla)$ cells were seeded into 6-well plates and grown to confluency. To prepare cell lysates, monolayers from some of the wells were harvested in $0.2 \mathrm{ml}$ growth media by scraping and then sonicated. Different amounts of these lysates were then added to the remaining viable monolayers of the same cell line that were cultured in parallel, i.e., HeLa lysates were added to HeLa monolayers. The final volume in each well was $2 \mathrm{ml}$. Lysates were used undiluted for the highest lysate concentration (100\%). Cultures were incubated for 8$10 \mathrm{~h}$ after which $\mathrm{IL}-8$ concentrations in the supernatants were determined. The amount of IL-8 present in lysates alone before culture ranged from 20 to $350 \mathrm{pg} / \mathrm{ml} \mathrm{IL-8} \mathrm{(equivalent} \mathrm{to} 4-50 \times 10^{-18} \mathrm{grams} / \mathrm{cell}$ ), and was subtracted as background. Data points are means \pm SEM of the results of three independent experiments.

secretion by viable monolayers of those cells. Moreover, this response was comparable in magnitude to that seen after $E$. histolytica infection of HeLa and WI38 cells (Table I). Although the cell lysates added to the monolayers themselves contained small amounts of IL-8 $\left(4-50 \times 10^{-18} \mathrm{grams} / \mathrm{cell}\right)$, this accounted for $<0.5 \%$ of the total IL- 8 in the lysate-stimulated culture supernatants. Similar findings were obtained with lysates from I407, T84, and CCD-18Co cells. In contrast, lysates from HT29 and HepG2 cells did not stimulate IL-8 secretion by those cells (Fig. 4).

Several cytokines, including TNF $\alpha, \mathrm{IL}-1 \alpha$, and IL- $1 \beta$, are known to induce increased IL-8 secretion by HeLa and WI38 cells (36). Moreover, epithelial cells and fibroblasts can express TNF $\alpha, \mathrm{IL}-1 \alpha$, and IL-1 $\beta$ (38). Therefore, we tested the possibility that one or more of these cytokines might be present in the cell lysates and responsible for increased IL-8 secretion after addition of cell lysates to the monolayers. For these experiments, anticytokine antibodies were added to lysates from HeLa, T84, I407, and WI38 cells, after which IL-8 secretion by viable test cells (HeLa) was assessed. As shown in Table III, anti-IL- $1 \alpha$ antibodies or IL-1Ra blocked $>90 \%$ of the lysate-induced $\mathrm{IL}-8$ response, whereas antibodies against $\mathrm{IL}-1 \beta$ or TNF $\alpha$ had no effect on this response. Anti-IL- $1 \alpha$ antibodies or IL-1Ra, but not anti-IL-1 $\beta$ or anti-TNF $\alpha$ antibodies, also were shown to block $>50 \%$ of the IL-8 inducing activity in lysates from CCD-18Co colon fibroblasts and human intestinal smooth muscle (HISM) cells. In all cell lysates tested, some of the IL-8 stimulating activity remained and could not be neutralized, even with high concentrations of inhibitors of $\mathrm{IL}-1 \alpha$ activity.

A possible explanation for the inability of lysates of HT29 and HepG 2 cells to induce IL- 8 secretion by these cells was a lack of IL- $1 \alpha$ responsiveness of those cells. However, this was not the case since IL-8 secretion of HT29 and HepG2 cells 


\begin{tabular}{|c|c|c|c|c|c|c|c|}
\hline \multirow[b]{2}{*}{ Experiment } & \multirow[b]{2}{*}{ Stimulators added } & \multicolumn{6}{|c|}{ IL-8 secreted $(\mathrm{pg} / \mathrm{ml})^{\ddagger}$} \\
\hline & & $\begin{array}{c}\text { No inhibitor } \\
\text { added }\end{array}$ & + Anti-IL-1 $\alpha$ & + Anti-IL-1 $\beta$ & + Anti-TNF $\alpha$ & $+\underset{\text { IgG }}{+ \text { Normal goat }}$ & $\begin{array}{c}+ \text { IL-1 receptor } \\
\text { antagonist }\end{array}$ \\
\hline \multirow[t]{5}{*}{1} & HeLa Lysate & $29,540 \pm 1,287$ & $648 \pm 36$ & $32,193 \pm 3,818$ & $29,855 \pm 1,377$ & $30,369 \pm 1,738$ & $791 \pm 94$ \\
\hline & $\mathrm{IL}-1 \alpha(50 \mathrm{pg} / \mathrm{ml})$ & $65,110 \pm 4,545$ & $255 \pm 21$ & $56,574 \pm 781$ & $49,825 \pm 10,222$ & $60,644 \pm 3,482$ & $321 \pm 40$ \\
\hline & $\mathrm{IL}-1 \beta(50 \mathrm{pg} / \mathrm{ml})$ & $58,076 \pm 1,595$ & $79,218 \pm 5,189$ & $265 \pm 28$ & $67,090 \pm 1,683$ & $70,945 \pm 4,304$ & $404 \pm 8$ \\
\hline & $\mathrm{TNF} \alpha(500 \mathrm{pg} / \mathrm{ml})$ & $3,000 \pm 157$ & $2,469 \pm 324$ & $2,513 \pm 337$ & $235 \pm 36$ & $2,936 \pm 23$ & $2,338 \pm 119$ \\
\hline & None & $365 \pm 61$ & $251 \pm 32$ & $295 \pm 48$ & $319 \pm 75$ & $297 \pm 48$ & $337 \pm 81$ \\
\hline \multirow[t]{4}{*}{2} & T84 Lysate & $1,035 \pm 75$ & $62 \pm 3$ & $927 \pm 29$ & $970 \pm 23$ & $876 \pm 26$ & $86 \pm 1$ \\
\hline & I407 Lysate & $60,812 \pm 2,517$ & $120 \pm 8$ & $55,458 \pm 2,896$ & $59,962 \pm 4,030$ & $59,346 \pm 1,041$ & $397 \pm 5$ \\
\hline & $\mathrm{TNF} \alpha(200 \mathrm{ng} / \mathrm{ml})$ & $4,313 \pm 74$ & N.D. ${ }^{\S}$ & N.D. & N.D. & N.D. & N.D. \\
\hline & None & $43 \pm 3$ & N.D. & N.D. & N.D. & N.D. & N.D. \\
\hline \multirow[t]{3}{*}{3} & WI38 Lysate & $749 \pm 51$ & $76 \pm 3$ & $711 \pm 65$ & $782 \pm 38$ & $772 \pm 8$ & $76 \pm 2$ \\
\hline & $\mathrm{TNF} \alpha(200 \mathrm{ng} / \mathrm{ml})$ & $2,727 \pm 69$ & N.D. & N.D. & N.D. & N.D. & N.D. \\
\hline & None & $40 \pm 3$ & N.D. & N.D. & N.D. & N.D. & N.D. \\
\hline
\end{tabular}

* Confluent monolayers of HeLa cells in 24-well plates were incubated with combinations of stimulators and inhibitors for $8 \mathrm{~h}$, after which IL-8 concentrations in the supernatants were determined by ELISA. The following stimulators and inhibitors were used: lysates from HeLa cells (10\% final concentration), T84 cells ( $50 \%$ final concentration), I407 cells ( $2 \%$ final concentration), WI38 cells (10\% final concentration), rhIL- $1 \alpha$, rhIL$1 \beta$, rhTNF $\alpha$, purified goat anti-human IL- $1 \alpha$, IL-1 $\beta$, or TNF $\alpha$ antibodies $(10 \mu \mathrm{g} / \mathrm{ml} \mathrm{each})$, normal goat IgG (10 $\mu \mathrm{g} / \mathrm{ml})$, and rhIL-1Ra (400 ng/ $\mathrm{ml})$. Cell lysates were prepared from confluent monolayers in 10-cm dishes in a 2-ml vol using DME medium, supplemented with $10 \%$ fetal calf serum. ${ }^{\ddagger}$ Numbers are mean \pm SEM of the results of triplicate cultures from a representative experiment. Similar results were obtained in at least one additional experiment for each tested cell lysate. ${ }^{8}$ N.D., not done.

increased after IL- $1 \alpha$ stimulation $(10 \mathrm{ng} / \mathrm{ml} \mathrm{IL-1} \alpha$ stimulated a 240 -fold and 100 -fold increase in IL-8 secretion by HT29 and HepG2 cells, respectively). Despite a requirement for a greater IL- $1 \alpha$ concentration to stimulate IL- 8 secretion by HT2 9 cells $\left(\mathrm{ED}_{50}=1,500 \mathrm{pg} \mathrm{IL}-1 \alpha / \mathrm{ml}\right)$ and HepG2 cells $\left(\mathrm{ED}_{50}=140 \mathrm{pg}\right.$ IL- $1 \alpha / \mathrm{ml})$ compared with HeLa cells $\left(\mathrm{ED}_{50}=50 \mathrm{pg} \mathrm{IL-1} \alpha /\right.$ $\mathrm{ml})$ or WI38 cells $\left(\mathrm{ED}_{50}=55 \mathrm{pg} \mathrm{IL}-1 \alpha / \mathrm{ml}\right)$, addition of lysates from HeLa or WI38 cells to HT29 or HepG2 cells induced IL8 secretion. In contrast, lysates from HT29 and HepG2 cells did not increase IL- 8 secretion by HeLa or WI38 cells. Furthermore, HT29 and HepG2 cell lysates did not appear to contain inhibitors of IL- $1 \alpha$ activity since no inhibition of IL- $1 \alpha$ bioactivity was seen when titrated doses of rhIL- $1 \alpha$ were added to HT29 or HepG2 cell lysates. Thus, the failure of HT29 and HepG2 cell lysates to stimulate increased IL-8 secretion appears to reflect a lack of IL-1 $\alpha$ activity in the lysates of these cells. This conclusion is supported by the previous finding that HT29 cells had $<10^{3}$ IL- $1 \alpha$ mRNA molecules/ $\mu$ g cellular RNA (38).

$I L-1 \alpha$ is released during $E$. histolytica infection and its effect on $I L-8$ secretion is blocked by IL-1 $\alpha$ specific inhibitors. To confirm that $\mathrm{IL}-1 \alpha$ is released during $E$. histolytica infection, cell monolayers were cocultured with increasing numbers of trophozoites, and IL- $1 \alpha$ concentrations in the culture supernatants were determined by ELISA. In parallel, monolayers were lysed by sonication and the concentration of released IL- $1 \alpha$ was measured. As shown in Fig. 5 for I407 cells, E. histolytica trophozoites were effective at stimulating IL- $1 \alpha$ release over a range of inocula. The highest $E$. histolytica inoculum caused rapid and complete cell lysis of 1407 cells and, in these cultures, the IL- $1 \alpha$ concentration in supernatants was similar to that measured in cell monolayers that were lysed by sonication. This confirmed that $E$. histolytica-induced cell lysis and cell lysis after sonication were equally effective in causing the release of preformed IL-1 $\alpha$. Since less cell lysis was observed at lower $E$. histolytica inocula, if IL-1 $\alpha$ was derived solely from the release of preformed cytokine, lower concentrations of IL-1 $\alpha$ would be expected in the supernatants. However, substantially greater quantities of IL- $1 \alpha$ than predicted were present in these supernatants (Fig. 5), indicating that, in addition to release of preformed IL- $1 \alpha$, IL- $1 \alpha$ synthesis was increased during infection. Similarly, increased IL- $1 \alpha$ concentrations were detected in HeLa and WI38 monolayers after $E$. histolytica infection

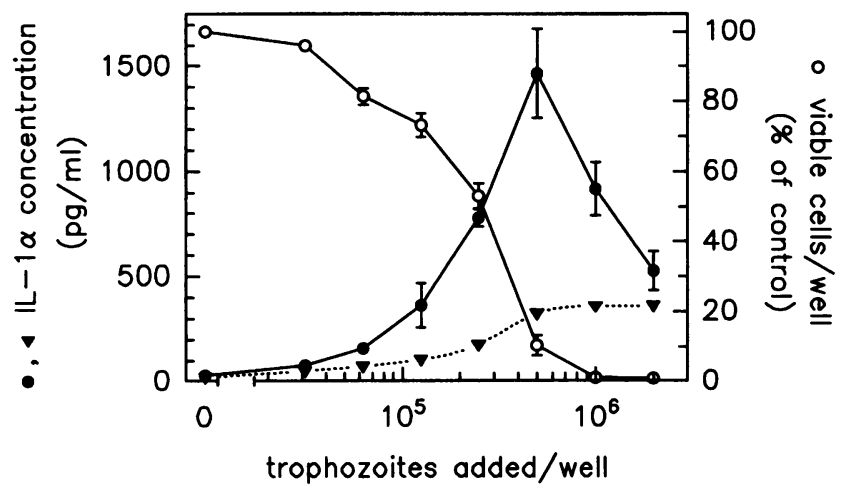

Figure 5. Release of IL-1 $\alpha$ in E. histolytica infected cell cultures. Confluent monolayers of 1407 cells in 6-well plates were infected with different numbers of $E$. histolytica trophozoites in a 2-ml vol. After 8 $h$ in culture, supernatants were removed and IL- $1 \alpha$ concentrations were determined by ELISA $(\bullet)$. In parallel, the number of viable cells in the monolayers was determined, and is expressed as a percentage of the number of viable cells in uninfected control cultures $(O)$. Control cultures contained a mean of $3.9 \times 10^{6}$ cells per well. To estimate the contribution of preformed intracellular IL-1 $\alpha$ to the total IL- $1 \alpha$ in the supernatants for each $E$. histolytica inoculum, uninfected monolayers were lysed by sonication in a $2-\mathrm{ml}$ volume and the IL- $1 \alpha$ concentration in the sonicate was multiplied by the fraction of cells that were lysed in response to each $E$. histolytica inoculum ( $\nabla$, dotted line). Data points are means \pm SEM of the results of three independent experiments. 


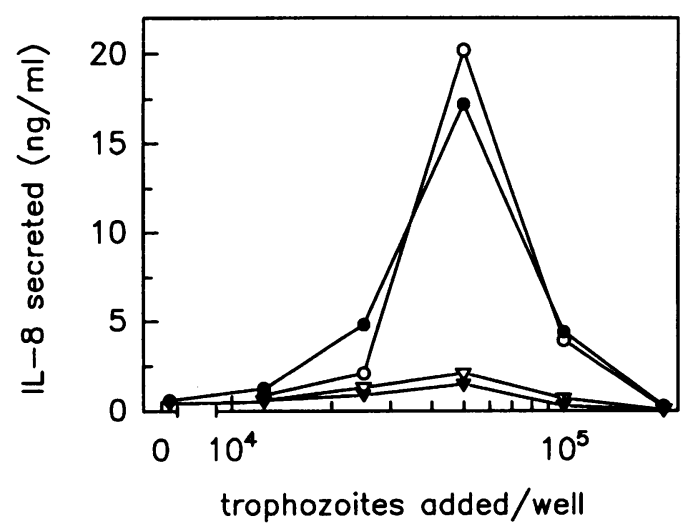

Figure 6. Inhibitors of IL-1 $\alpha$ activity block IL-8 secretion by HeLa cells in response to $E$. histolytica. Confluent HeLa cell monolayers in 24-well plates were infected with varying numbers of $E$. histolytica trophozoites in a $0.4-\mathrm{ml}$ vol in the presence of $20 \mu \mathrm{g} / \mathrm{ml}$ goat anti-IL$1 \alpha$ antibodies $(\nabla), 300 \mathrm{ng} / \mathrm{ml} \mathrm{rhIL}-1 \mathrm{Ra}(\nabla), 20 \mu \mathrm{g} / \mathrm{ml}$ normal goat $\operatorname{IgG}(O)$, or without added inhibitors $(\bullet)$. After $8 \mathrm{~h}$, IL-8 concentrations in the supernatants were assayed. Data represent the mean of triplicate cultures from a representative experiment. SEM, omitted from the figure for clarity, were $<20 \%$ for all data points. Similar results were obtained in two additional experiments using either polyclonal goat anti-IL-1 $\alpha$ or monoclonal mouse anti-IL-1 $\alpha$ antibodies $(10 \mu \mathrm{g} / \mathrm{ml})$.

(HeLa cells: controls $<5 \mathrm{pg} / \mathrm{ml}$, infected $94 \mathrm{pg} / \mathrm{ml}$; WI38 cells: controls $<5 \mathrm{pg} / \mathrm{ml}$, infected $59 \mathrm{pg} / \mathrm{ml}$ ). In further studies, increased IL-1 $\alpha$ mRNA levels were found after $E$. histolytica infection. Thus, unstimulated HeLa and WI38 cells contained $5 \times 10^{4}$ and $1 \times 10^{3} \mathrm{IL}-1 \alpha$ mRNA molecules $/ \mu \mathrm{g}$ total cellular RNA, respectively. In contrast, after $8 \mathrm{~h}$ coculture with $E$. histolytica, HeLa and WI38 cells contained $4 \times 10^{6}$ and $3 \times 10^{5}$ IL- $1 \alpha$ mRNA molecules/ $\mu$ g total RNA, respectively.

Cell lysates contained soluble $\mathrm{IL}-1 \alpha$, as determined for HeLa cells, since ultracentrifugation $(100,000 \mathrm{~g}, 30 \mathrm{~min}) \mathrm{did}$ not decrease the ability of HeLa cell lysates to induce IL-8 secretion by these cells. Moreover, as tested in 1407 cell lysates, $>95 \%$ of the IL- $1 \alpha$ had a molecular mass of $33 \mathrm{kD}$, as assessed by Western blot analysis, indicating that most IL- $1 \alpha$ in the cell lysates was present as the unprocessed precursor. In contrast, supernatants from 1407 cells cocultured with $E$. histolytica contained only $50 \%$ of the $I L-1 \alpha$ as the $33-\mathrm{kD}$ precursor and the remainder as the $17-\mathrm{kD}$ mature form. A similar 1:1 distribution of $\mathrm{IL}-1 \alpha$ precursor and mature form was observed after incubation of 1407 cell lysates with trophozoites for $8 \mathrm{~h}$ at $37^{\circ} \mathrm{C}$, whereas the distribution of precursor and mature form was not altered after incubation of the $\mathbf{I 4 0 7}$ cell lysates under identical conditions without trophozoites (i.e., an $\sim 20: 1$ ratio of precursor: mature form). This indicates that $E$. histolytica trophozoites or their secreted products can convert IL- $1 \alpha$ precursor into the mature form of IL- $1 \alpha$.

We next determined if $I L-1 \alpha$ mediated the increase in IL8 secretion that was observed after infection of the cell monolayers with $E$. histolytica. As shown in Fig. 6, addition of antiIL- $1 \alpha$ antibodies or IL-1Ra to HeLa cells cocultured with $E$. histolytica reduced IL-8 secretion $>90 \%$, whereas control antibodies had no effect on increased IL-8 secretion. Similarly, increased GM-CSF secretion was not seen when anti-IL-1 $\alpha$ antibodies were added to $E$. histolytica-infected HeLa cell cultures, indicating that IL- $1 \alpha$ also mediated the induction of that cytokine. The extent of $E$. histolytica-induced HeLa cell lysis was not affected by antibody addition. In further experiments, increased IL-8 secretion by $\mathrm{I} 407$ cells in response to $E$. histolytica infection was inhibited $>80 \%$ if anti-IL- $1 \alpha$ antibodies or IL-1Ra was added to culture. In contrast, increased IL-8 secretion by HepG 2 and HT2 2 cells after infection of the monolayers with $E$. histolytica was not affected by the addition of anti-IL$1 \alpha$ antibodies or IL-1Ra, further documenting that increased $\mathrm{IL}-8$ secretion by those cells was not mediated by IL- $1 \alpha$ release.

Induction of IL-8 secretion requires viable $E$. histolytica trophozoites. These studies indicate that release of $\mathrm{IL}-1 \alpha$ is a crucial host cell mechanism to induce high-level IL-8 secretion after $E$. histolytica infection. To address the parasite factors which are important for this response, we first assessed whether $E$. histolytica membrane molecules or secreted $E$. histolytica products affect IL-8 secretion. Nonviable trophozoites (boiled for $3 \mathrm{~min}$, or fixed with $1 \%$ formaldehyde for $30 \mathrm{~min}$ at $4^{\circ} \mathrm{C}$ ) did not induce $I L-8$ secretion by HeLa cells $(21 \mathrm{pg} \mathrm{IL-8/ml} \mathrm{in}$ the supernatants of uninfected confluent control monolayers in 24-well plates, $12,046 \mathrm{pg} / \mathrm{ml}$ in cultures infected with $5 \times 10^{4}$ viable trophozoites, $20 \mathrm{pg} / \mathrm{ml}$ in cultures infected with $5 \times 10^{4}$ boiled trophozoites, and $27 \mathrm{pg} / \mathrm{ml}$ in cultures infected with 5 $\times 10^{4}$ fixed trophozoites).

Similarly, freshly prepared lysates of $E$. histolytica, obtained by sonication on ice and tested at a range of concentrations (50-650 $\mu \mathrm{g} / \mathrm{ml}$ total amebic protein), had little effect on IL-8 secretion by HeLa cells ( $57 \mathrm{pg} \mathrm{IL-8/ml} \mathrm{in} \mathrm{the} \mathrm{supernatants} \mathrm{of}$ untreated confluent control monolayers in 24-well plates, 43 $\mathrm{pg} / \mathrm{ml}$ in the presence of $50 \mu \mathrm{g} / \mathrm{ml}$ amebic lysate, and $52 \mathrm{pg} /$ $\mathrm{ml}$ with $650 \mu \mathrm{g} / \mathrm{ml}$ amebic lysate), and HT29 cells (174 pg $\mathrm{IL}-8 / \mathrm{ml}$ in the supernatants of untreated confluent control monolayers in 24-well plates, $204 \mathrm{pg} / \mathrm{ml}$ in the presence of 50 $\mu \mathrm{g} / \mathrm{ml}$ amebic lysate, and $312 \mathrm{pg} / \mathrm{ml}$ with $650 \mu \mathrm{g} / \mathrm{ml}$ amebic lysate), and no effect on IL-8 secretion by T84 cells ( $<30 \mathrm{pg}$ IL- $8 / \mathrm{ml}$ in control cultures and in the presence of $650 \mu \mathrm{g} / \mathrm{ml}$ amebic lysate).

In further experiments, $E$. histolytica conditioned medium ( see Methods) was tested for its ability to stimulate IL-8 secretion by HeLa, HT29, and T84 cells under serum-free conditions, since serum components can inhibit the activity of some of the enzymes secreted by $E$. histolytica $(23,33)$. The adherent cell monolayers detached from the plates after addition of increasing concentrations of conditioned media, a cytopathic effect which has been associated with cysteine proteases released by $E$. histolytica (11). Nonetheless, conditioned media did not increase IL-8 secretion at all concentrations tested (2-50\% final concentration) (data not shown). Taken together, these results suggest that viable trophozoites, and not simply membrane molecules or secreted products of $E$. histolytica, are required for increased IL-8 secretion.

Role of the galactose-inhibitable amebic adherence protein in the epithelial cell IL-8 response to E. histolytica. Adherence of viable $E$. histolytica to target cells, and subsequent cell lysis, is mediated by a galactose-inhibitable adherence protein $(20$, 21,45 ). To investigate the role of this protein in the IL-8 response to $E$. histolytica, HeLa and HT29 monolayers were cocultured with trophozoites in the presence of galactose or $\mathrm{N}$-acetyl-galactosamine, carbohydrates which are reported to specifically block the adherence lectin $(20,45)$, or glucose and fructose as osmotic controls. As shown in Fig. 7, $A$ and $B$, galactose shifted the dose-response curve for both IL-8 secretion and cell lysis by HeLa cells to higher trophozoite inocula, but did not affect maximal IL-8 secretion compared with the osmotic controls. In the presence of galactose, a twofold higher 

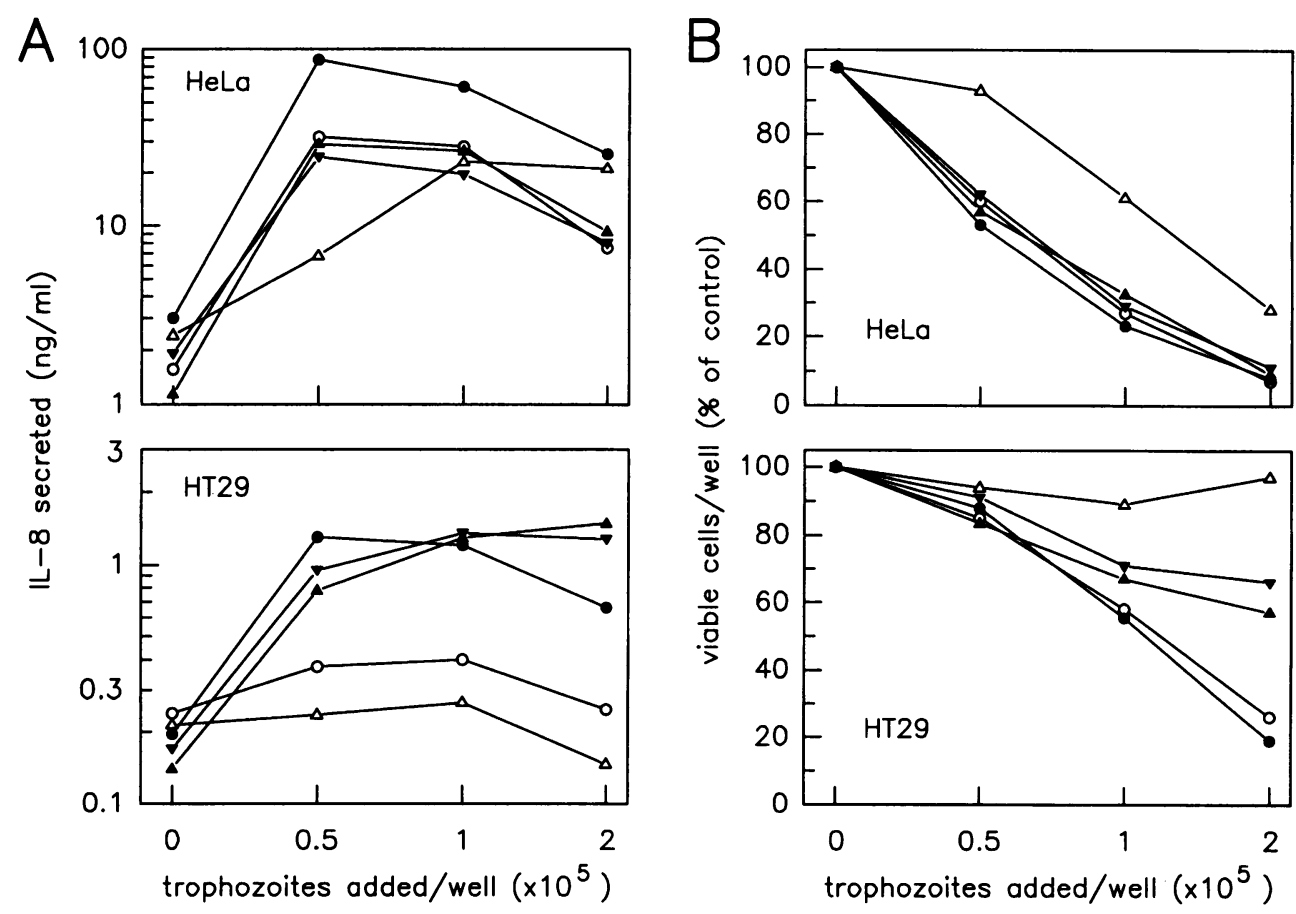

Figure 7. Carbohydrate inhibition of $E$. histolytica-induced IL-8 secretion. Confluent monolayers of HeLa and HT29 cells in 24-well plates were infected with $0.5-2$ $\times 10^{5} \mathrm{E}$. histolytica trophozoites in the presence of $100 \mathrm{mM}$ each of galactose $(\nabla), \mathrm{N}$-acetyl-galactosamine $(O)$, glucose $(\nabla)$, fructose ( $\triangle$ ), or without added carbohydrates $(\bullet)$, and incubated for 6 h. Trophozoite viability was not affected by the added carbohydrates during the 6-h culture period. Values are means of the results from three independent experiments. $(A)$ Supernatants were removed, and IL-8 concentrations were determined by ELISA. The two- to threefold inhibition of maximal IL-8 secretion in response to $E$. histolytica infection of HeLa cells in the presence of added carbohydrates likely is a nonspecific effect and was also noted after IL- $1 \alpha$ or TNF $\alpha$ stimulation (data not shown). (B)

The number of viable cells remaining in the monolayers at the end of the culture period was determined by trypan blue dye exclusion, and is expressed as a percentage of the number of viable cells present in uninfected control cultures. Control cultures contained a mean of $3.9 \times 10^{5}$ $(\mathrm{HeLa})$ and $1.1 \times 10^{6}($ HT29) cells/well.

number of trophozoites was required to induce maximal IL-8 secretion compared with $E$. histolytica-infected control cultures containing glucose or fructose. The finding that $\mathrm{IL}-8$ secretion and target cell lysis are closely correlated in HeLa cells after $E$. histolytica infection supports the conclusion that target cell lysis and the release of IL- $\alpha$ are important for the induction of IL-8 secretion in response to E. histolytica infection.

In HT29 cells, IL-8 secretion was not closely correlated with target cell lysis, indicating that the IL-8 response of these cells was not dependent on cell lysis. IL-8 secretion by HT29 cells in response to $E$. histolytica was almost completely blocked by both galactose and $\mathrm{N}$-acetyl-galactosamine (Fig. 7 $A$ ) irrespective of whether or not cell lysis was blocked (Fig. 7 B) (i.e., galactose blocked cell lysis whereas $N$-acetyl-galactosamine did not). Further, glucose and fructose did not inhibit the increase in IL-8 secretion, although they also significantly decreased target cell lysis after $E$. histolytica infection. These data indicate that the contact through the galactose-inhibitable amebic adherence protein, rather than cell lysis, is most important for the IL-8 response of HT29 cells to E. histolytica infection. Moreover, the data with HT29 cells define a further mechanism in addition to the cytolytic release of cellular IL$1 \alpha$ for the induction of IL-8 after $E$. histolytica infection. This mechanism appears to be most relevant for cells that lack preformed IL- $1 \alpha$.

Increases in intracellular calcium are paralleled by moderate increases in IL-8 secretion. Increased levels of intracellular calcium in target cells after contact with trophozoites are thought to be required as an intermediate event for subsequent cell lysis (46). Moreover, the increased intracellular calcium levels have been reported to be mediated by the galactoseinhibitable amebic adherence protein (46). Since the above studies showed that the galactose-inhibitable amebic adherence protein was important for the IL-8 response to E. histolytica, we tested the possibility that increases in intracellular calcium would increase IL-8 secretion. As shown in Table IV, stimulation of HT29 cells (which lack preformed IL- $1 \alpha$ ) or T84 cells (which do not respond to IL-1 $\alpha$ ) with the calcium elevating agents, thapsigargin (47) and ionomycin, resulted in an increased IL-8 secretion to levels approximating those seen after $E$. histolytica infection. The same agents also elevated IL-8 secretion moderately in HeLa cells, although the increases were considerably lower than those seen after $E$. histolytica infection (Table I). These data are consistent with the possibility that the amebic adherence protein could mediate increases in IL-8 secretion, at least in part, by an increase in intracellular calcium levels after $E$. histolytica infection.

Table IV. Calcium-elevating Agents Induce IL-8 Secretion by Epithelial Cells*

\begin{tabular}{lrcc}
\hline & \multicolumn{3}{c}{ IL-8 secreted $(\mathrm{pg} / \mathrm{ml})$} \\
\cline { 2 - 4 } Cells & Control & + Thapsigargin & + Ionomycin \\
\hline HT29 & 400 & 3,394 & 699 \\
T84 & 73 & 1,249 & 514 \\
HeLa & 631 & 3,217 & 1,482 \\
\hline
\end{tabular}

* Confluent monolayers of epithelial cell lines in 24-well plates were cultured for $6 \mathrm{~h}$ in the presence of $1 \mu \mathrm{M}$ thapsigargin or $1 \mu \mathrm{M}$ ionomycin. Since stocks of these agents were prepared in DMSO, control cultures were incubated with the same final concentration of DMSO $(0.02 \%)$. Supernatants were removed, and IL-8 concentrations were determined by ELISA. Numbers are means of the results of two or three independent experiments. 


\section{Discussion}

E. histolytica trophozoites stimulated increased secretion of an array of chemoattractant and proinflammatory cytokines, including IL-8, GRO $\alpha$, GM-CSF, IL-6, and IL-1 $\alpha$ from human epithelial and stromal cell lines of varying origins. Moreover, as shown for IL-8, increased cytokine secretion was paralleled by increased gene transcription and steady state mRNA levels. These cytokines, particularly IL-8, GRO $\alpha$, and GM-CSF, are known to govern PMN localization and function. Thus, IL-8 and GRO $\alpha$ are potent PMN chemoattractants in vitro and in vivo (48). In addition, IL-8 increases the secretion of myeloperoxidase and other antimicrobial proteins by PMNs (35), and GM-CSF increases PMN survival and the capacity of PMNs to phagocytose microbial pathogens (49). The local release of these cytokines, and possibly additional cytokines induced through mechanisms similar to those described herein, along with a direct effect of $E$. histolytica products on PMN migration (50), can explain the histopathologic finding of PMN infiltration in acute experimental $E$. histolytica infection $(22,24,25)$.

The cytolytic release of IL- $1 \alpha$ was important for initiating the secretion of inflammatory cytokines in response to $E$. histolytica infection. IL-1 $\alpha$ appears particularly well suited for this function since it differs in several aspects from most other proinflammatory cytokines. The unprocessed $31-33 \mathrm{kD} \mathrm{IL-} \alpha$ precursor is bioactive with a specific activity that is only twofold lower than that of the mature $17-\mathrm{kD}$ form (51), whereas the precursor form of IL-1 $\beta$, for example, requires proteolytic processing by an IL-1 $\beta$ converting enzyme for bioactivity (52). Moreover, IL- $1 \alpha$ induces physiologic responses at low concentrations $(1-10 \mathrm{pg} / \mathrm{ml})$, whereas other proinflammatory cytokines, particularly the chemokines, require substantially higher concentrations $(>10 \mathrm{ng} / \mathrm{ml})$ to mediate their biological activity (48). Unlike other cytokines, IL-1 $\alpha$ lacks an amino terminal signal peptide required for efficient secretion (53), which suggests that IL-1 $\alpha$ may exert some of its activities in the absence of secretion (54). Despite the absence of a signal peptide, it is known that IL- $\alpha$ can be secreted by cells in the mature form in response to various stimuli (53). For example, murine macrophages secrete IL- $1 \alpha$ after LPS stimulation (53), or after infection with Shigella flexneri (55). In contrast, keratinocytes do not secrete IL-1 $\alpha$, although they have high levels of intracellular $\mathrm{IL}-1 \alpha$ whose biological functions are unknown (53).

These studies suggest a physiologic role of intracellular IL$1 \alpha$ in the host response to lytic pathogens. In this role, membrane damage causes the release of constitutively expressed, intracellular IL- $1 \alpha$ precursor, which can activate a cascade of proinflammatory events in the immediate vicinity of the lysed cells. Membrane damage and subsequent cell lysis may be secondary to contact with a cytolytic pathogen such as $E$. histolytica, but this principle may also apply to other pathogens which cause cell lysis such as Chlamydia trachomatis or Rotavirus. Further, we showed that IL- $1 \alpha$ released by damaged cells can increase IL- $1 \alpha$ production by neighboring cells. Such a mechanism could serve to amplify the inflammatory response by increasing the capacity of neighboring cells to release additional IL- $1 \alpha$ when they are damaged.

Whereas most epithelial cell lines contained preformed, intracellular IL-1 $\alpha$, some epithelial cell lines, like HT29, lacked this cytokine. Consistent with this finding, only a fraction of intestinal epithelial may express a particular cytokine as shown, for example, for IL-6 (56). This suggests that a minimum number of intestinal epithelial cells (i.e., a lower threshold number) must be lysed before sufficient $\mathrm{IL}-1 \alpha$ is released to initiate secretion of IL-8 and other proinflammatory cytokines. In contrast to some of the epithelial cells, the stromal cells tested (i.e., fibroblasts and smooth muscle cells) expressed preformed IL$1 \alpha$, suggesting that once $E$. histolytica has penetrated through the intestinal epithelium deeper into the intestinal mucosa, lysis of a comparatively smaller number of mucosal host cells is sufficient to initiate an inflammatory response.

Increased IL-8 secretion was not mediated by released IL$1 \alpha$ in HT29 and HepG2 cells cocultured with trophozoites, and these cells showed a lower IL-8 response to $E$. histolytica infection. Other cells, like T84, express IL-1 $\alpha$ but do not respond to that cytokine since they lack type I IL-1 receptors (Kagnoff, M. F., unpublished data). Nonetheless, the doseresponse curves for IL-8 secretion and for target cell lysis were comparable in all these cells, indicating that those cells were not resistant to the effects of $E$. histolytica. Our data indicate that IL-8 secretion by HT29 and HepG 2 cells may be induced by signalling pathways that result in increased intracellular calcium levels. This was shown directly by demonstrating that pharmacologic agents that increased intracellular calcium levels induced IL-8 secretion, and indirectly by showing that blocking a galactose-inhibitable amebic adherence protein known to mediate an increase in intracellular calcium levels (46) also blocked IL-8 secretion in HT29 cells. The lower IL-8 response of HT29 to E. histolytica, compared to other cells, may also be explained by the fact that direct trophozoite target cell contact, which is required for increased levels of intracellular calcium (46) ultimately leads to cell lysis (45).

IL-8 and GRO $\alpha$, produced by host epithelial and stromal cells in response to $E$. histolytica, are potent chemoattractants and activators of PMNs. In addition, $E$. histolytica products can attract human PMNs $(50,57)$. The relative contribution of host cell-derived and ameba-derived activities to the chemoattraction of PMNs is not known. However, the host cytokine response demonstrated herein also can activate PMN functions, such as the release of microbicidal enzymes (35), and initiate mechanisms that result in tissue inflammation. For example, IL-1 upregulates adhesion molecules for inflammatory cells on the endothelium (53), and induces prostaglandin production which may contribute to the diarrhea often associated with $E$. histolytica infection (58). Infiltration of host tissues with PMNs is seen early in the response to $E$. histolytica infection in animal models $(22,24,25)$. However, the role of PMNs in the host's defense to acute $E$. histolytica infections has not been clearly defined. Thus, nonactivated PMNs were lysed by virulent $E$. histolytica trophozoites in vitro (57). In contrast, cytokine-activated PMNs killed the free living amebas, Acanthamoeba and Naegleria $(59,60)$, as well as virulent $E$. histolytica trophozoites (61). These data suggest that PMNs may play a role in the first line of defense against acute $E$. histolytica infection, for example, by reducing the initial trophozoite load.

These studies used cell lines which may have lost or altered differentiated cell functions during the transformation process. However, the data suggest that the observed cellular responses to $E$. histolytica are likely representative of the physiologic host response in vivo. Thus, essentially identical cytokine responses to $E$. histolytica were observed using cells of different origin, cell lineage and differentiation stage, and in several nontransformed cells including CCD-18Co colon fibroblasts and HISM jejunal smooth muscle cells (34). Cell lines have the advantage over freshly isolated cells that they permit the study of cell types in isolation. This is crucial, for example, for demonstrating 
the importance of low levels of intracellular IL-1 $\alpha$ in the cellular response to $E$. histolytica, since even small numbers of highly IL-1 $\alpha$ expressing cells in freshly isolated cell populations, such as macrophages (53), would have confounded the results.

Finally, we further note that cytokines secreted in response to E. histolytica, in addition to attracting and activating PMNs, may contribute to other aspects of the clinical picture in acute $E$. histolytica infections. In this respect, IL-1 is a potent pyrogen (53), and fever is commonly seen in acute systemic infection with $E$. histolytica (58). Moreover, IL-6, locally produced at the infection site, can induce the production of acute phase proteins, which are detected in patients with amebic liver abscesses $(44,62)$. Finally, increased serum IL-8 levels, as we have noted in some patients with amebic liver abscesses (Eckmann, L., and S. L. Reed, unpublished observations ), may contribute to the leukocytosis found in patients with invasive amebiasis (63).

\section{Acknowledgments}

We thank Scott Herdman for expert technical assistance.

L. Eckmann is a research fellow of the Crohn's \& Colitis Foundation of America. This work was supported by National Institutes of Health grants DK35108 and AI28035, and a grant from the Pediatric AIDS Foundation.

\section{References}

1. Walsh, J. A. 1986. Problems in recognition and diagnosis of amebiasis: estimation of the global magnitude of morbidity and mortality. Rev. Infect. Dis. $8: 228-238$.

2. Nanda, R., U. Baveja, and B. S. Anand. 1984. Entamoeba histolytica cyst passers: clinical features and outcome in untreated subjects. Lancet ii:301-303.

3. Sargeaut, P. G., J. E. Williams, and J. D. Greene. 1978. The differentiation of invasive and noninvasive Entamoeba histolytica by isoenzyme electrophoresis. Trans. R. Soc. Trop. Med. Hyg. 72:519-521.

4. Edman, U., M. A. Meraz, S. Rausser, N. Agabian, and I. Meza. 1990. Characterization of an immuno-dominant variable surface antigen from pathogenic and nonpathogenic Entamoeba histolytica. J. Exp. Med. 172:879-888.

5. Edman, U., I. Meza, and N. Agabian. 1987. Genomic and cDNA actin sequences from a virulent strain of Entamoeba histolytica. Proc. Natl. Acad. Sci. USA. 84:3024-3028.

6. Tannich, E., R. D. Horstmann, J. Knobloch, and H. H. Arnold. 1989. Genomic DNA differences between pathogenic and nonpathogenic Entamoeba histolytica. Proc. Natl. Acad. Sci. USA. 86:5118-5122.

7. Que, X., and S. L. Reed. 1991. Nucleotide sequence of a small subunit ribosomal RNA (16S-like rRNA) gene from Entamoeba histolytica: differentiation of pathogenic from nonpathogenic isolates. Nucleic Acids Res. 19:5438.

8. Garfinkel, L. I., M. Giladi, M. Huber, C. Gitler, D. Mirelman, M. Revel, and S. Rozenblatt. 1989. DNA probes specific for Entamoeba histolytica possessing pathogenic and nonpathogenic zymodemes. Infect. Immun. 57:926-931.

9. Clark, C. G., and L. S. Diamond. 1991. Ribosomal RNA genes of 'pathogenic' and 'nonpathogenic' Entamoeba histolytica are distinct. Mol. Biochem. Parasitol. 49:297-302.

10. Tannich, E., H. Scholze, R. Nickel, and R. D. Horstmann. 1991. Homologous cysteine proteinases of pathogenic and nonpathogenic Entamoeba histolytica: differences in structure and expression. J. Biol. Chem. 266:4798-4803.

11. Reed, S., J. Bouvier, A. S. Pollack, J. C. Engel, M. Brown, K. Hirata, X. Que, A. Eakin, P. Hagbloom, F. Gillin, and J. H. McKerrow. 1993. Cloning of a virulence factor of Entamoeba histolytica. Pathogenic strains possess a unique cysteine proteinase gene. J. Clin. Invest. 91:1532-1540.

12. Sargeaut, P. G. 1992. 'Entamoeba histolytica' is a complex of two species. Trans. R. Soc. Trop. Med. Hyg. 86:348.

13. Walsh, J. A. 1988. Prevalence of Entamoeba histolytica infection. In Amebiasis: Human Infection by Entamoeba histolytica. J.I. Ravdin, editor. John Wiley \& Sons, New York. 93-105.

14. Vinayak, V. K., N. L. Chitkara, and P. N. Chuttani. 1979. Effect of corticosteroid and irradiation on caecal amoebic infection in rats. Trans. R. Soc. Trop. Med. Hyg. 73:266-274.

15. Ghadirian, E., and E. Meerovitch. 1981. Effect of immunosuppression on the size and metastasis of amoebic liver abscesses in hamsters. Parasite Immunol. (Oxf.). 3:329-338.

16. Cieslak, P. R., H. W. Virgin, and S. L. Stanley. 1992. A severe combined immunodeficient (SCID) mouse model for infection with Entamoeba histolytica. J. Exp. Med. 176:1605-1609.

17. Salata, R. A., and J. I. Ravdin. 1986. The interaction of human neutrophils and Entamoeba histolytica increases cytopathogenicity for liver cell monolayers. J. Infect. Dis. 154:19-26.

18. Perez-Tamayo, R., R. D. Martinez, I. Montfort, I. Becker, E. Tello, and R. Perez-Montfort. 1991. Pathogenesis of acute experimental amebic liver abscess in hamsters. J. Parasitol. 77:982-988.

19. Chadee, K., W. A. Petri, D. J. Innes, and J. I. Ravdin. 1987. Rat and human colonic mucins bind to and inhibit adherence lectin of Entamoeba histolytica. $J$. Clin. Invest. 80:1245-1254.

20. Petri, W. A., R. D. Smith, P. H. Schlesinger, C. F. Murphy, and J. I. Ravdin. 1987. Isolation of the galactose-binding lectin that mediates the in vitro adherence of Entamoeba histolytica. J. Clin. Invest. 80:1238-1244.

21. Petri, W. A. M. D. Chapman, T. Snodgrass, B. J. Mann, J. Broman, and J. I. Ravdin. 1989. Subunit structure of the galactose and $N$-acetyl-D-galactosamine-inhibitable adherence lectin of Entamoeba histolytica. J. Biol. Chem. 264:3007-3012.

22. Takeuchi, A., and B. P. Phillips. 1975. Electron microscope studies of experimental Entamoeba histolytica infections in the guinea pig. I. Penetration of the intestinal epithelium by trophozoites. Am. J. Trop. Med. Hyg. 24:34-48.

23. Keene, W. E., M. G. Petitt, S. Allen, and J. H. McKerrow. 1986. The major neutral proteinase of Entamoeba histolytica. J. Exp. Med. 163:536-549.

24. Chadee, K., and E. Meerovitch. 1985. The pathology of experimentally induced cecal amebiasis in gerbils (Meriones unguiculatus): liver changes and amebic liver abscess formation. Am. J. Pathol. 119:485-494.

25. Martinez-Palomo, A., V. Tsutsumi, F. Anaya-Velazquez, and A. GonzalezRobles. 1989. Ultrastructure of experimental intestinal invasive amebiasis. Am. J. Trop. Med. Hyg. 41:273-279.

26. Leippe, M., E. Sebastian, O. L. Schoenberger, R. D. Horstmann, and H. J. Müller-Eberhard. 1991. Pore-forming peptide of pathogenic Entamoeba histolytica. Proc. Natl. Acad. Sci. USA. 88:7659-7663.

27. Long-Krug, S. A., K. J. Fischer, R. M. Hysmith, and J. I. Ravdin. 1985 Phospholipase A enzymes of Entamoeba histolytica: description and subcellular localization. J. Infect. Dis. 152:536-541.

28. Jansson, A., F. Gillin, U. Kagardt, and P. Hagbloom. 1994. Coding of hemolysins within the ribosomal RNA repeat on a plasmid in Entamoeba histolytica. Science (Wash. DC). 263:1440-1443.

29. Chadee, K., and E. Meerovitch. 1984. The pathogenesis of experimentally induced amebic liver abscess in the gerbil (Meriones unguiculatus). Am. J. Pathol. 117:71-80.

30. Tsutsumi, V., R. Mena-Lopez, F. Anaya-Velazquez, and A. MartinezPalomo. 1984. Cellular bases of experimental amebic liver abscess formation. Am. J. Pathol. 117:81-91.

31. Tsutsumi, V., and A. Martinez-Palomo. 1988. Inflammatory reaction in experimental hepatic amebiasis: an ultrastructural study. Am. J. Pathol. 130:112119.

32. Brandt, H., and R. Perez-Tamayo. 1970. Pathology of human amebiasis. Hum. Pathol. 1:351-385.

33. Reed, S. L., W. E. Keene, J. H. McKerrow, and I. Gigli. 1989. Cleavage of C3 by a neutral cysteine proteinase of Entamoeba histolytica. J. Immunol. 143:189-195.

34. Graham, M. F., R. F. Diegelmann, C. O. Elson, K. N. Bitar, and H. P. Ehrlich. 1984. Isolation and culture of human intestinal smooth muscle cells. Proc. Soc. Exp. Biol. Med. 176:503-507.

35. Schröder, J.-M., U. Mrowietz, E. Morita, and E. Christophers. 1987. Purification and partial biochemical characterization of a human monocyte-derived, neutrophil-activating peptide that lacks interleukin 1 activity. J. Immunol. 139:3474-3483.

36. Eckmann, L., M. F. Kagnoff, and J. Fierer. 1993. Epithelial cells secrete the chemokine interleukin-8 in response to bacterial entry. Infect. Immun. 61:4569-4574.

37. Chomczynski, P., and N. Sacchi. 1987. Single-step method of RNA isolation by acid guanidinium thiocyanate-phenol-chloroform extraction. Anal. Biochem. 162:156-159.

38. Jung, H. C., L. Eckmann, S.-K. Yang, A. Panja, J. Fierer, E. MorzyckaWroblewska, and M. F. Kagnoff. 1995. A distinct array of proinflammatory cytokines is expressed in human colon epithelial cells in response to bacterial invasion. J. Clin. Invest. 95:55-65.

39. Mukaida, N., M. Shiroo, and K. Matsushima. 1989. Genomic structure of the human monocyte-derived neutrophil chemotactic factor IL-8. J. Immunol. 143:1366-1371.

40. van Zonneveld, A.-J., S. A. Curriden, and D. J. Loskutoff. 1988. Type 1 plasminogen activator inhibitor gene: functional analysis and glucocorticoid regulation of its promoter. Proc. Natl. Acad. Sci. USA. 85:5525-5529.

41. Gunning, P., J. Leavitt, G. Muscat, S.-Y. Ng, and L. Kedes. 1987. A human $\beta$-actin expression vector system directs high-level accumulation of antisense transcripts. Proc. Natl. Acad. Sci. USA. 84:4831-4835.

42. Chen, C., and H. Okayama. 1987. High-efficiency transformation of mammalian cells by plasmid DNA. Mol. Cell. Biol. 7:2745-2752.

43. Jain, V. K., and I. T. Magrath. 1991. A chemiluminescent assay for 
quantitation of $\beta$-galactosidase in the femtogram range: application to quantitation of $\beta$-galactosidase in lacZ-transfected cells. Anal. Biochem. 199:119-124.

44. Ahmed, M., K. P. McAdam, A. W. Sturm, and R. Hussain. 1992. Systemic manifestations of invasive amebiasis. Clin. Infect. Dis. 15:974-982.

45. Ravdin, J. I., and R. L. Guerrant. 1981. Role of adherence in cytopathogenic mechanisms of Entamoeba histolytica. Study with mammalian tissue culture cells and human erythrocytes. J. Clin. Invest. 68:1305-1313.

46. Ravdin, J. I., F. Moreau, J. A. Sullivan, W. A. Petri, and G. L. Mandell. 1988. Relationship of free intracellular calcium to the cytolytic activity of Entamoeba hystolytica. Infect. Immun. 56:1505-1512.

47. Thastrup, O., P. J. Cullen, B. K. Drobak, M. R. Hanley, and A. P. Dawson. 1990. Thapsigargin, a tumor promoter, discharges intracellular $\mathrm{Ca}^{2+}$ stores by specific inhibition of the endoplasmic reticulum $\mathrm{Ca}^{2+}$-ATPase. Proc. Natl. Acad. Sci. USA. 87:2466-2470.

48. Baggliolini, M., B. Dewald, and B. Moser. 1994. Interleukin-8 and related chemotactic cytokines-CXC and CC chemokines. Adv. Immunol. 55:97-179.

49. Fabian, I., Y. Kletter, S. Mor, C. Geller-Bernstein, M. Ben-Yaakov, B. Volovitz, and D. W. Golde. 1992. Activation of human eosinophil and neutrophil functions by haematopoietic growth factors: comparisons of IL-1, IL-3, IL-5 and GM-CSF. Br. J. Haematol. 80:137-143.

50. Salata, R. A., P. Ahmed, and J. I. Ravdin. 1989. Chemoattractant activity of Entamoeba histolytica for human polymorphonuclear neutrophils. J. Parasitol. 75:644-646.

51. Mosley, B., S. K. Dower, S. Gillis, and D. Cosman. 1987. Determination of the minimum polypeptide lengths of the functionally active sites of human interleukins $1 \alpha$ and $1 \beta$. Proc. Natl. Acad. Sci. USA. 84:4572-4576.

52. Howard, A. D., M. J. Kostura, N. Thornberry, G. J. F. Ding, G. Limjuco, J. Weidner, J. P. Salley, K. A. Hogquist, D. D. Chaplin, R. A. Mumford, et al 1991. IL-1-converting enzyme requires aspartic acid residues for processing of the $\mathrm{IL}-1 \beta$ precursor at two distinct sites and does not cleave $31-\mathrm{kDa}$ IL- $1 \alpha$. J. Immunol. 147:2964-2969.
53. Dinarello, C. A. 1994. Interleukin-1. Adv. Pharmacol. 25:21-51.

54. Maier, J. A. M., M. Statuto, and G. Ragnotti. 1994. Endogenous interleukin 1 alpha must be transported to the nucleus to exert its activity in human endothelial cells. Mol. Cell. Biol. 14:1845-1851.

55. Zychlinsky, A., C. Fitting, J.-M. Cavaillon, and P. J. Sansonetti. 1994. Interleukin 1 is released by murine macrophages during apoptosis induced by Shigella flexneri. J. Clin. Invest. 94:1328-1332.

56. Shirota, K., L. LeDuy, S. Yuan, and S. Jothy. 1990. Interleukin-6 and its receptor are expressed in human intestinal epithelial cells. Virchows Arch. B Cell Pathol. 58:303-308.

57. Guerrant, R. L., J. Brush, J. I. Ravdin, J. A. Sullivan, and G. L. Mandell. 1981. Interaction between Entamoeba histolytica and human polymorphonuclear neutrophils. J. Infect. Dis. 143:83-93.

58. Reed, S. L. 1992. Amebiasis: an update. Clin. Infect. Dis. 14:385-393.

59. Ferrante, A., and T. J. Abell. 1986. Conditioned medium from stimulated mononuclear leukocytes augments human neutrophil-mediated killing of a virulent Acanthamoeba sp. Infect. Immun. 51:607-617.

60. Michelson, M. K., W. R. Henderson, E. Y. Chi, T. R. Fritsche, and S. J. Klebanoff. 1990. Ultrastructural studies on the effect of tumor necrosis factor on the interaction of neutrophils and Naegleria fowleri. Am. J. Trop. Med. Hyg. 42:255-233.

61. Denis, M., and K. Chadee. 1989. Human neutrophils activated by interferon- $\gamma$ and tumour necrosis factor- $\alpha$ kill Entamoeba histolytica trophozoites in vitro. J. Leukocyte Biol. 46:270-274.

62. Katzenstein, D., V. Rickerson, and A. Braude. 1982. New concepts of amebic liver abscess derived hepatic imaging, serodiagnosis and hepatic enzymes in 67 consecutive cases in San Diego. Medicine (Baltimore). 61:237-246.

63. Simonet, W. S., T. M. Hughes, H. Q. Nguyen, L. D. Trebasky, D. M. Danilenko, and E. S. Medlock. 1994. Long-term impaired neutrophil migration in mice overexpressing human interleukin-8. J. Clin. Invest. 94:1310-1319. 